\title{
Asesmen Potential Review pada Karyawan Rumah Sakit XX dalam Pengembangan Sumber Daya Manusia
}

\author{
Donni Revi Ardhi ${ }^{1}$, Dian Fithriwati Darusmin ${ }^{2}$ \\ ${ }^{1,2}$ Fakultas Psikologi, Universitas Ahmad Dahlan \\ Jl. Kapas, No. 9, Semaki, Umbulharjo, Kota Yogyakarta, Daerah Istimewa Yogyakarta, 55166 \\ 1'donni1707043026@webmail.uad.ac.id \\ 2dian.darusmin@psy.uad.ac.id
}

\begin{abstract}
Abstrak
Rumah sakit merupakan salah satu tempat yang menyediakan jasa pelayanan pada bidang kesehatan. Rumah sakit yang semakin berkembang, mengharuskan karyawan medis maupun non medis untuk bekerja dengan memberikan pelayanan yang prima kepada pelanggan, sehingga masing-masing karyawan dituntut untuk bekerja dengan optimal berdasarkan kemampuan yang dimiliki. Penelitian ini bertujuan untuk mengukur potensi yang dimiliki oleh karyawan yang mengikuti evaluasi kinerja dan sebagai pemenuhan kebutuhan pengembangan diri karyawan RS XX. Subjek dalam penelitian ini sebanyak 1 orang yang berada posisi supervisor penagihan. Metode pengumpulan data menggunakan tes psikologi dan wawancara. Analisis data menggunakan analisis deskriptif dan analisis kualitatif. Hasil asesmen menunjukkan bahwa subjek memenuhi standar potensi yang diharapkan pada posisi supervisor penagihan dengan rekomendasi masih dapat dipertimbangkan dan perlu dilakukan pengembangan pada aspek daya tahan stres lebih lanjut. Kesimpulan asesmen potenial review pada posisi supervisor penagihan diperlukan pengembangan melalui program counselling, agar subjek mampu mengelola stres yang dimiliki dengan baik, sehingga subjek tetap mampu bekerja dengan optimal.
\end{abstract}

Kata Kunci: Tinjuan Potensi; Pengembangan Sumber Daya Manusia; Daya Tahan Stres

\begin{abstract}
The hospital is one place that provides services in the health sector. Hospitals are increasingly developing, requiring medical and non-medical employees to work by providing excellent service to customers, so that each employee is required to work optimally based on their capabilities. This study aims to measure the potential possessed by employees who take part in performance evaluations and as meeting the personal development needs of XX Hospital employees. The subjects in this study were 1 person who was in the position of billing supervisor. Data collection methods use psychological tests and interviews. Data analysis uses descriptive analysis and qualitative analysis. The results of the assessment indicate that the subject meets the potential standards expected at the position of the billing supervisor with recommendations that can still be considered and further development of the stress resistance aspect is needed. Conclusion Potential review review on billing supervisor position requires development through counseling program, so that the subject is able to manage stress well, so that the subject is still able to work optimally.
\end{abstract}

Keywords: Potential Review; Human Resources Development; Stress Endurance

\section{PENDAHULUAN}

Rumah sakit merupakan salah satu tempat pelayanan dalam bidang jasa kesehatan. Rumah sakit terbagi 2 yaitu baik rumah sakit yang dikelola oleh pemerintah ataupun rumah sakit yang dikelola pihak swasta. Salah satu rumah sakit umum yang dikelola oleh pihak swasta yang berada di Kota Pekanbaru adalah RS XX. RS XX termasuk dalam rumah sakit tipe B. Rumah sakit ini menjunjung tinggi nilai-nilai Islam setiap pelayanan yang diberikan kepada pasiennya, sehingga sesuai dengan visi rumah sakit "Terwujudnya RS XX Pekanbaru yang bermutu, islami, dan dapat ditauladani”. Perkembangan zaman yang semakin cepat membuat 
RS XX harus mampu bertahan dan mengembangkan organisasi, salah satunya dengan cara mengembangkan sumber daya manusia (SDM) yang ada diorganisasi, sehingga rumah sakit memiliki SDM yang berkualitas dan mampu memberikan pelayanan yang memuaskan kepada pasien ataupun yang berhubungan dengan perusahaan lainnya.

Ketidakpuasan pelanggan memunculkan sejumlah risiko, seperti boikot atau protes dari lembaga konsumen, komplain pelanggan, intervensi pemerintah, reaksi pesaing dan masuknya produk subtitusi baru ke pasar, sehingga perusahaan perlu mengantisipasi komplain oleh pelanggan rumah sakit dengan cara meningkatkan kemampuan karyawan sesuai dengan potensi yang dimilikinya (Tjiptono, 2006)

Organisasi memiliki tanggung jawab terhadap karyawan ketika karyawan diterima untuk bekerja, dimana perusahan harus mampu mempersiapkan pengembangan kepada setiap karyawan yang berada di dalam sebuah organisasi. Selain itu, organisasi juga harus mampu mengidentifikasi potensi apa saja yang dimiliki oleh setiap karyawannya. Perusahaan dituntut untuk dapat melakukan assesmen secara komprehensif dengan melihat potensi yang dimiliki oleh karyawan, memetakan potensi dan mengembangkan area-area yang berada dibawah standar yang ditetapkan oleh perusahaan. Hal ini sesuai dengan pendapat Hasibuan (2013) mengatakan peranan manajemen sumber daya manusia salah satunya adalah Menetapkan penarikan, seleksi, dan penempatan karyawan berdasarkan orang yang tepat dan tempat yang tepat dan orang yang tepat dalam pekerjaan yang tepat. Salah satu langkah yang digunakan untuk melakukan penilaian terhadap potensi yang dimiliki oleh karyawan adalah dengan melakukan asesmen potential review. Hal ini sesuai dengan pernyataan (Dharmaraj \& Sulaiman, 2015) yang menyebutkan salah satu bentuk praktik manajemen SDM adalah potential review untuk mengevaluasi kapasitas baik kognitif maupun kepribadian seorang karyawan.

Potential review diperlukan sebagai media pengembangan pribadi seseorang agar membantu seseorang untuk mengenali kemampuan-kemampuannya, sehingga nantinya perusahaan dapat menggunakan hasil dari potential review tersebut untuk melakukan berbagai macam proses manajemen sumber daya manusia, seperti sebagai inventaris profil dari karyawan yang akan dipromosikan, mutasi, rotasi dan lain-lain (Munandar, 2010). Karyawan yang memiliki kinerja dan kompetensi yang baik, tentu akan mempengaruhi produktifitas organisasi dengan meningkatnya jumlah pengunjung rumah sakit. Putra (2017) menjelaskan bahwa kompetensi atau competency adalah kemampuan untuk melaksanakan suatu tugas/ pekerjaan yang didasari atas pengetahuan, keterampilan dan sikap sesuai dengan bidang kerja.

Selama ini, rolling jabatan yang dilakukan RS XX dalam pelaksanaannya tidak menggunakan asesmen tes psikologi maupun proses wawancara, sehingga rumah sakit tidak mengetahui gambaran secara mendalam potensi kemampuan yang dimiliki oleh karyawan, sehingga perlu dilakukan potential review untuk mengetahui potensi kemampuan yang dimiliki karyawan tersebut untuk mengetahui potensi yang dimiliki dan menentukan pengembangan lebih lanjut untuk meningkatkan potensi yang dimilikinya agar dapat bekerja dengan optimal. Asesmen potential review ini dapat dilakukan pada setiap level jabatan, sehingga organisasi dapat mengetahui gambaran potensi karyawan yang dilakukan secara berkala.

Dengan demikian penelitian ini ditujukan untuk melakukan potential review pada posisi supervisor penagihan adalah untuk melihat kesesuaian antara job description dengan potensi yang dimiliki oleh karyawan, sehingga dapat merencanakan pengembangan lebih lanjut terkait dengan potensi karyawan pada posisi supervisor penagihan RS XX. 


\section{METODE}

Metode yang digunakan dalam asesmen potential review yang dilakukan pada posisi supervisor penagihan di RS XX adalah menggunakan dua metode, yaitu metode tes psikologi dan metode non tes, yakni wawancara. Tes psikologi yang digunakan, seperti Intelligenz Struktur Test (IST), Tes Kraeplin, Tes Perception and Preference Inventory (PAPI) Kostick, Tes Grafis (Draw a Tree, Draw a Person, dan House Tree Person), dan Tes Wartegg, sedangkan metode non tes lain yang digunakan adalah wawancara dengan teknik Behavioral Event Interview (BEI) sebanyak 1 kali.

Subjek yang digunakan dalam penelitian ini adalah seorang Supervisor Penagihan dengan jenis kelamin perempuan dan berusia 30 tahun. Adapun tanggungjawabnya sebagai berikut: 1. Bertanggungjawab terhadap pelaksanaan protap-protap yang ada. 3. Terlaksananya koordinasi yang baik di bagian keuangan. Uraian jabatan seorang Supervisor Penagihan adalah sebagai berikut: 1 . Melakukan pemeriksaan terhadap kebenaran data-data tagihan yang dikirim ke perusahaan. 2. Merencanakan, mengkoordinasi dan mengawasi langsung pekerjaan staf. 3. Melakukan pemeriksaan terhadap laporan dan hasil kerja staf piutang dan penagihan. 4. Melakukan pemeriksaan \& pengawasan terhadap piutang-piutang yang akan dan sudah jatuh tempo. 5. Menghubungi dan mengingatkan perusahaan lain, karyawan dan perorangan sebelum piutang jatuh tempo. 6. Menghubungi perusahaan, karyawan dan perorangan jika piutang sudah jatuh tempo untuk segera melakukan pembayaran. 7. Melakukan pengawasan dan crosscheck pembayaran piutang oleh perusahaan, pasien umum \& karyawan RS XX dan yayasan. 8 . Melakukan verifikasi dan memberikan rekomendasi kepada pimpinan terhadap pasien-pasien yang tidak mampu. 9. Menyiapkan, membuat dan mengisi dokumen-dokumen seperti surat pernyataan dan surat hutang piutang.

\section{Metode Tes}

Tes yang digunakan dalam penelitian ini seperti: 1. Intelligenz Struktur Test (IST). Tes ini biasa digunakan untuk mengambarkan arah pengembangan individu, baik digunakan dalam lingkungan pendidikan (jurusan) maupun untuk kebutuhan pekerjaan. IST juga digunakan untuk mengambarkan struktur potensi intelektual individu. 2. Tes Kraeplin. Tes ini menghasilkan perhitungan objektif yang dapat diungkap dalam empat aspek bakat, yaitu: kecepatan kerja (Panker), ketelitian kerja (Tianker), keajegan kerja (Janker) dan ketahanan kerja (Hanker) (Sahyadi \& Harsanti, 2018). 3. Tes Perception and Preference Inventory (PAPI) Kostick. Alat ini cukup peka dalam mengukur need dan role yang menjadi overt dalam perilaku kerja, sehingga peka untuk mengukur adjustment dalam lingkungan kerja, peka terhadap perubahan lingkungan kerja berhubungan dengan pindah kerja atau perubahan jabatan, dan peka terhadap perlakuan lingkungan berhubungan dengan konseling, pelatihan dan sebagainya. 4. Tes BAUM/Draw a Tree (DAT). Tes ini juga mampu merefleksikan suatu self projection dari dunia dalam seseorang atau tingkat personality yang tidak disadari.

Menurut (Savira \& Hidayat, 2017) tes BAUM (tes gambar pohon) sama seperti tes proyektif lainnya merepresentasikan struktur kepribadian id-ego-super ego dari pandangan Freud. Menurut (Sahyadi \& Harsanti, 2018) tes BAUM (tes gambar pohon) sama seperti tes proyektif lainnya merepresentasikan struktur kepribadian id-ego-super ego dari pandangan Freud. 5. Tes Draw a Person (DAP). Tes menggambar orang atau draw a person atau the drawing human figure diciptakan oleh Karen Machover pada tahun 1949, yang merupakan suatu metode proyeksi dari kepribadian orang yang menggambarnya. 6. Tes House Tree Person (HTP).H ouse tree person (HTP) mengungkap tentang pola keluarga individu (Nurhayati \& 
Santoso, 2018). 7. Tes Wartegg. Tes wartegg berkembang sejak awal 1920-an dan 1930-an, dipelopori oleh Ehrigg Wartegg bermula di negara Jerman hingga saat ini di Indonesia masih berkembang dan terus digunakan (Prabowo, Nisa', \& Jadmiko, 2016). Tes Wartegg menggunakan teknik proyektif, yaitu teknik yang diberikan melalui stimulus-stimulus yang tidak terstruktur dan ambigu (Roivainen, 2009). Tes Wartegg merupakan salah satu asesmen tes psikologi yang digunakan untuk evaluasi kepribadian (personality assessment).

\section{Metode Non Tes}

Asesmen non tes yang dilakukan menggunakan wawancara semi terstruktur. Wawancara adalah percakapan dengan maksud tertentu. Percakapan dilakukan oleh dua pihak, yaitu pewawancara (interviewer) yang mengajukan pertanyaan dan terwawancara (interviewee) yang memberikan jawaban atas pertanyaan itu (Moloeng, 2012). Maksud mengadakan wawancara, seperti ditegaskan oleh (Lincoln \& Guba, 1985), antara lain: mengkonstruksi mengenai orang, kejadian, organisasi, perasaan, motivasi, tuntutan, kepedulian dan lain-lain kebulatan: merekonstruksi kebulatan-kebulatan demikian sebagai yang dialami masa lalu; memproyeksikan kebulatan-kebulatan sebagai yang diharapkan untuk dialami pada masa yang akan datang; memverifikasi, mengubah dan memperluas informasi yang diperoleh dari orang lain, baik manusia maupun bukan manusia (triangulasi); dan memverifikasi, mengubah dan memperluas konstruksi yang dikembangkan oleh peneliti sebagai pengecekan anggota. Teknik wawancara yang digunakan dalam asesmen ini adalah Behaviral Event Interview (BEI). Behaviral event interview (BEI) adalah teknik wawancara dengan cara menggali informasi mengenai perilaku seseorang yang pernah dilakukannya secara nyata (Wikansari, 2014).

Berdasarkan dari tanggung jawab, wewenang dan uraian jabatan yang dimiliki oleh Supervisor Penagihan, maka aspek psikologi yang diperlukan untuk menduduki jabatan tersebut, sebagai berikut:

\section{Tabel 1.}

Profil Potensi Aspek Psikologi Supervisor Penagihan

\begin{tabular}{|c|c|c|c|c|c|c|}
\hline \multirow{2}{*}{ Aspek Psikologi } & \multirow{2}{*}{ Defenisi } & \multicolumn{5}{|c|}{ Level } \\
\hline & & 1 & 2 & 3 & 4 & 5 \\
\hline Intelegensi Umum & $\begin{array}{l}\text { Kemampuan untuk bertindak secara terarah, berpikir secara } \\
\text { rasional, dan menghadapi lingkungannya secara efektif. }\end{array}$ & & & & & \\
\hline Berpikir Analitis & $\begin{array}{l}\text { Kemampuan pemahaman situasi/masalah dengan } \\
\text { menguraikannya menjadi bagian-bagian kecil secara logis, } \\
\text { atau melacak implikasi dari masalah atau situasi tersebut } \\
\text { secara bertahap. }\end{array}$ & & & & & \\
\hline Ketelitian & $\begin{array}{l}\text { Dorongan untuk mengurangi ketidakpastian } \mathrm{di} \\
\text { lingkungannya. }\end{array}$ & & & & & \\
\hline Sistematika Kerja & $\begin{array}{l}\text { Kemampuan untuk mempelajari dan menerapkan } \\
\text { serangkaian langkah, aturan atau panduan yang diperlukan } \\
\text { untuk melaksanakan suatu tugas, tanggung jawab atau peran } \\
\text { tertentu. }\end{array}$ & & & & & \\
\hline $\begin{array}{l}\text { Kemampuan } \\
\text { Melayani }\end{array}$ & $\begin{array}{l}\text { Keinginan untuk membantu atau melayani pelanggan untuk } \\
\text { memenuhi kebutuhan mereka. }\end{array}$ & & & & & \\
\hline Inisiatif & $\begin{array}{l}\text { Dorongan untuk melakukan sesuatu yang melebihi tuntutan } \\
\text { tugas, melakukan hal-hal yang tidak diminta oleh siapapun, } \\
\text { yang dapat meningkatkan hasil kerja dan mencegah } \\
\text { terjadinya masalah, atau menemukan/menciptakan peluang- } \\
\text { peluang baru. }\end{array}$ & & & & & \\
\hline
\end{tabular}




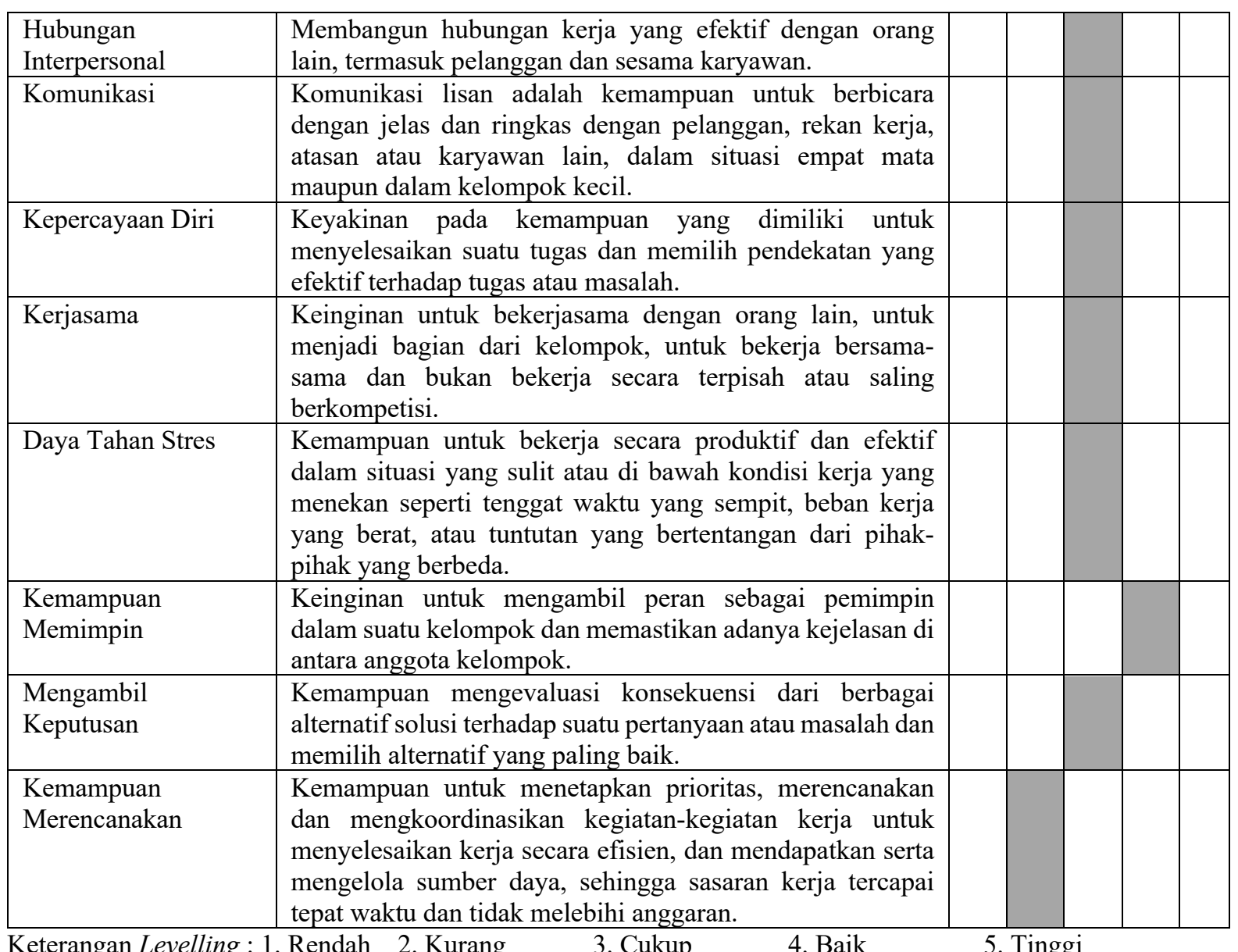

\section{Matriks Metode Pengambilan Data}

Beberapa metode tes dan non tes yang dilakukan pada asesmen potential review ini dapat dilihat pada matriks di bawah ini:

Tabel 2.

Matriks Metode Pengambilan Data

\begin{tabular}{|c|c|c|c|c|c|c|c|c|}
\hline \multirow{2}{*}{$\begin{array}{c}\text { Aspek } \\
\text { Psikologis }\end{array}$} & \multicolumn{8}{|c|}{ Alat Ukur } \\
\hline & IST & $\begin{array}{c}\text { PAPI } \\
\text { Kostick }\end{array}$ & Kraeplin & BAUM & DAP & HTP & Wartegg & Wawancara \\
\hline $\begin{array}{l}\text { Intelegansi } \\
\text { Umum }\end{array}$ & $\sqrt{ }$ & & & & & & & \\
\hline Berpikir Analitis & $\sqrt{ }$ & & & & & & & $\sqrt{ }$ \\
\hline Ketelitian & & & $\sqrt{ }$ & & & & & $\sqrt{ }$ \\
\hline $\begin{array}{l}\text { Sistematika } \\
\text { Kerja }\end{array}$ & & $\sqrt{ }$ & $\sqrt{ }$ & & & & & $\sqrt{ }$ \\
\hline $\begin{array}{l}\text { Kemampuan } \\
\text { Melayani }\end{array}$ & & $\sqrt{ }$ & & & & & & $\sqrt{ }$ \\
\hline Inisiatif & & & & & & & & $\sqrt{ }$ \\
\hline $\begin{array}{l}\text { Hubungan } \\
\text { Interpersonal }\end{array}$ & & $\sqrt{ }$ & & $\sqrt{ }$ & & & & $\sqrt{ }$ \\
\hline Komunikasi & & & & & & & & $\sqrt{ }$ \\
\hline Kepercayaan Diri & & $\sqrt{ }$ & & $\sqrt{ }$ & $\sqrt{ }$ & & & $\sqrt{ }$ \\
\hline
\end{tabular}




\begin{tabular}{llllll}
\hline Kerjasama & $\sqrt{ }$ & & & & $\sqrt{ }$ \\
\hline Daya Tahan Stres & $\sqrt{ }$ & $\sqrt{ }$ & $\sqrt{ }$ & $\sqrt{ }$ \\
\hline Memimpin & $\sqrt{ }$ & & & & $\sqrt{ }$ \\
Kelompok & & & & $\sqrt{ }$ \\
\hline Mengarahkan & $\sqrt{ }$ & & & $\sqrt{ }$ \\
\hline $\begin{array}{l}\text { Mengambil } \\
\text { Keputusan }\end{array}$ & & & & $\sqrt{ }$ \\
\hline Memampuan & & & \\
\hline Kemampanakan & & & \\
Membina & & & & \\
\hline
\end{tabular}

HASIL

Hasil tes psikologi dan wawancara asesmen potential review yang telah dilakukan kepada subjek dengan jabatan Supervisor Penagihan di RS XX, didapatkan hasil dengan masingmasing metode sebagai berikut:

Tabel 3.

Matriks Hasil Asesmen

\begin{tabular}{|c|c|c|c|c|c|c|c|c|c|c|c|}
\hline $\begin{array}{c}\text { Aspek } \\
\text { Psikologis }\end{array}$ & IST & Kraeplin & $\begin{array}{c}\text { PAPI } \\
\text { Kostick }\end{array}$ & (DAT) & (DAP) & (HTP) & Wartegg & Wawancara & Target & $\begin{array}{c}\text { Hasil } \\
\text { Aktual }\end{array}$ & GAP \\
\hline Intelegensi Umum & 3 & - & - & - & - & - & - & - & 3 & $3(\mathrm{C})$ & 0 \\
\hline Berpikir Analitis & 3 & - & - & - & - & - & - & 3 & 3 & $3(\mathrm{C})$ & 0 \\
\hline Ketelitian & - & 3 & 2 & - & - & - & - & 3 & 3 & $3(\mathrm{C})$ & 0 \\
\hline Sistematika Kerja & - & 3 & 2 & - & - & - & - & 4 & 3 & $3(\mathrm{C})$ & 0 \\
\hline $\begin{array}{l}\text { Kemampuan } \\
\text { Melayani }\end{array}$ & - & - & 3 & - & - & - & - & 4 & 3 & $4(\mathrm{~B})$ & +1 \\
\hline Inisiatif & - & - & - & - & - & - & - & 4 & 2 & $4(\mathrm{~B})$ & +2 \\
\hline $\begin{array}{l}\text { Hubungan } \\
\text { Interpersonal }\end{array}$ & - & - & 3 & 2 & - & - & 3 & 3 & 3 & $3(\mathrm{C})$ & 0 \\
\hline Komunikasi & - & - & - & - & - & - & - & 3 & 3 & $3(\mathrm{C})$ & 0 \\
\hline Kepercayaan Diri & - & - & 3 & 2 & 2 & - & 4 & 3 & 3 & $3(\mathrm{C})$ & 0 \\
\hline Kerjasama & - & - & 3 & - & - & - & - & 3 & 3 & $3(\mathrm{C})$ & 0 \\
\hline Daya Tahan Stres & - & 2 & 3 & - & 2 & 2 & 1 & 4 & 3 & $2(\mathrm{~K})$ & -1 \\
\hline $\begin{array}{l}\text { Memimpin } \\
\text { Kelompok }\end{array}$ & - & - & 3 & - & - & - & - & 3 & 4 & $3(\mathrm{C})$ & -1 \\
\hline $\begin{array}{l}\text { Mengambil } \\
\text { Keputusan }\end{array}$ & - & - & 2 & - & - & - & - & 3 & 3 & $3(\mathrm{C})$ & 0 \\
\hline $\begin{array}{l}\text { Kemampuan } \\
\text { Merencanakan }\end{array}$ & - & - & - & - & - & - & - & 4 & 2 & $4(\mathrm{~B})$ & +2 \\
\hline GAP & 2 & & & & & & & & & & \\
\hline$(+)$ & Mele & ihi dari gre & rea. & & & & & & & & \\
\hline$(-)$ & Kurar & g dari grey & & & & & & & & & \\
\hline (0) & Sesu & rey area. & & & & & & & & & \\
\hline
\end{tabular}

Keterangan : DAT; draw a tree, DAP; draw a person, HTP; house tree person

\section{DINAMIKA PSIKOLOGI}

Subjek memiliki potensi kecerdasan dalam kategori rata-rata, dengan potensi yang dimilikinya tersebut, ia cukup mampu menerima, memproses dan menyimpulkan informasi yang diterimanya dengan cukup baik. Disamping itu, ia juga cukup mampu menyelesaikan permasalahan yang bersifat sederhana dengan menguruaikan masalah kedalam bagian-bagian kecil, sehingga ia dapat menyimpulkan inti permasalahan yang ditemuinya. 
Ia juga cukup mampu untuk menyelesaikan pekerjaan dengan cukup teliti, sehingga ia cenderung mampu untuk mengantisipasi kesalahan ketika menyelesaikan pekerjaan yang menjadi tanggungjawabnya. Disisi lain, ia kurang memiliki minat untuk melakukan pekerjaan yang bersifat mendetail, sehingga ia cenderung menghindari pekerjaan tersebut dan memberikannya kepada orang lain. Disamping itu, ia juga merupakan individu yang cukup sistematis dalam menyelesaikan pekerjaan, sehingga tanggungjawab yang diberikannya dapat diselesaikan secara teratur.

Subjek juga merupakan individu yang memiliki kemampuan dalam memberikan pelayanan yang dibutuhkan orang lain, dikarenakan ia peduli dan terhadap kesulitan yang dirasakan oleh orang lain, sehingga ia mampu memberikan pelayanan yang baik. Disamping itu, ia juga membutuhkan perhatian dan cenderung memiliki ketergantungan terhadap orang lain, sehingga ia memiliki kebutuhan untuk membangun hubungan hangat dengan orang lain.

Subjek juga cukup memiliki kemampuan dalam berkomunikasi kepada orang lain. Kemampuan komunikasi yang dimilikinya cukup mampu mendukung pekerjaannya sebagai supervisor yang akan berhubungan dan melakukan komunikasi kepada bawahannya, seperti dalam menyampaikaan tugas dan tanggungjawab secara jelas dan dapat dimengerti oleh bawahannya. Selain itu, kemampuan komunikasi yang dimilikinya juga cukup membantunya dalam melakukan koordinasi kepada atasan maupun unit lain sesuai dengan tuntutan tugasnya. Disamping itu, ia juga cukup memiliki keyakinan terhadap pekerjaan yang akan dilakukannya, dikarenakan ia cukup optimis untuk dapat menyelesaikan tuntutan pekerjaan tanpa ada rasa ragu. Disisi lain, ia juga memiliki kecemasan dan kurang memiliki daya tahan terhadap pekerjaan yang penuh tekanan, sehingga ia kurang mampu untuk menyelesaikan pekerjaan tersebut dengan baik.

Subjek memiliki kemampuan untuk menyelesaikan pekerjaan tambahan yang diberikan atasan kepadanya dan membantu pekerjaan rekan kerjanya secara sukarela, dikarenakan ia merupakan individu yang cukup mampu membangun kerjasama dengan orang orang lain. Ia juga cukup memiliki komitmen dan loyal terhadap organisasi maupun atasannya, sehingga ia cenderung akan membantu tugas atasan dan rekan kerja yang lain jika dibutuhkan.

Subjek cukup mampu untuk memimpin orang lain dengan memberikan peran terhadap tugas dan tanggungjawab berdasarkan kemampuan yang dimiliki oleh bawahannya. Kemampuannya dalam memimpin, cukup memudahkannya dalam melakukan pengembangan melalui pembinaan ADM piutang umum, ADM piutang perusahaan, penagihan piutang dengan tujuan meningkatkan kinerja orang lain dan melakukan pengawasan serta evaluasi terhadap pekerjaan bawahannya. Kandidat juga cukup mampu untuk memutuskan sesuatu yang sifatnya mendesak dengan mempertimbangkan resiko dari keputusan yang akan diambil. Disisi lain, ia cenderung merasa ragu-ragu jika dihadapkan pada beberapa keputusan secara matang dengan alternatif yang ada. Kemampuan yang dimiliki ini cukup memudahkannya dalam memutuskan jika piutang jatuh tempo oleh perusahaan lain dan sanksi kepada bawahan. Disisi lain, ia juga memiliki kemampuan dalam membuat strategi dalam meningkatkan sistem komplain yang diberikan oleh konsumen, sehingga komplain pasien atau konsumen mampu diantisipasi dengan baik, serta membantu pekerjaan dengan lebih efektif.

Kesimpulannya, subjek memerlukan pengembangan pada aspek kepribadian dalam mengelola diri dari tekanan pekerjaan yang akan berdampak pada kinerjanya. Hal ini didukung dengan studi dokumen berupa data diri kandidat yang menyatakan bahwa ia memiliki kelemahan pada kontrol emosi yang kurang baik, sehingga dengan pengembangan yang dilakukan, ia mampu mengelola stres yang dimilikinya dengan baik dan memiliki daya tahan terhadap tekanan dan bekerja dengan produktif. Subjek perlu pengembangan menggunakan program counselling yang diharapkan kandidat mampu menemukan sumber masalah dan 
mampu mengelola diri dengan baik. Kandidat merupakan karyawan masih dapat dikembangkan yang masih memerlukan pengembangan pada aspek kepribadian, sehingga tidak menghambat kinerjanya dalam bekerja pada posisi supervisor penagihan.

Hasil pemeriksaan psikologis yang telah dilakukan, subjek memiliki aspek potensi yang memenuhi standar, seperti: pada aspek kemampuan intelektual, yaitu: aspek intelegensi umum dan berpikir analitis, aspek pola kerja, yaitu: ketelitian kerja dan sistematika kerja, pada aspek kepribadian, yaitu: hubungan interpersonal, komunikasi, kepercayaan diri dan kerjasama. Pada aspek kepemimpinan, yaitu: aspek mengambil keputusan. Sedangkan potensi yang melebihi standar pada aspek kepribadian, yaitu: kemampuan melayani, inisiatif dan aspek kepemimpinan, yaitu: kemampuan merencanakan dan potensi yang belum memenuhi standar, seperti pada aspek kepribadian, yaitu: daya tahan stres dan aspek kepemimpinan, seperti: memimpin kelompok.

Potensi intelensi umum subjek berada pada level 3. Potensi yang dimiliki subjek menunjukkan bahwa ia cukup mampu melakukan tindakan secara terarah sesuai dengan tujuan yang ada. Kemampuan ini sesuai dengan job description supervisor penagihan yaitu, memberikan masukan-masukan dalam bentuk saran-saran dan pemikiran kepada kepala bagian keuangan untuk perbaikan RS XX khususnya bagian piutang dan penagihan.

Potensi berpikir Analitis subjek berada pada level 3. Potensi yang dimiliki oleh menunjukkan bahwa ia cukup mampu menemukan sebab akibat permasalahan yang terjadi didalam kelompoknya, sehingga ia mampu mengenali inti permasalahan dengan cukup rinci dan menyimpulkan penyebab permasalahan yang terjadi.

Potensi ketelitian subjek berada pada level 3. Potensi yang dimiliki oleh subjek menunjukkan bahwa ia cukup mampu untuk memperhatikan secara detail pekerjaan yang dilakukannya, sehingga ia dapat mengantisipasi kesalahan yang mungkin akan terjadi ketika menyelesaikan suatu pekerjaan. Potensi ini sesuai dengan kebutuhan jabatan dan tanggunggungjawab subjek sebagai supervisor penagihan, yaitu dalam melakukan pemeriksaan terhadap kebenaran data-data tagihan yang dikirim ke perusahaan dan ketika melakukan pemeriksaan terhadap laporan dan hasil kerja staf piutang dan penagihan.

Potensi sistematika kerja subjek berada pada level 3. Potensi yang dimiliki subjek cukup mampu untuk melakukan pekerjaannya sesuai dengan prosedur yang berlaku. Selain itu, ia juga cukup mampu untuk menerapkan langkah-langkah pekerjaan dengan sistematis, sehingga cenderung jarang melewatkan setiap detail pekerjaan yang dilakukannya. Hal ini sesuai dengan

Potensi kemampuan melayani subjek berada pada level 4. Potensi yang dimiliki oleh subjek menunjukkan bahwa ia mampu memberikan pelayanan yang lebih dan memenuhi kebutuhan pelanggan atau rekan kerja yang membutuhkan bantuan. Ia mampu menggali informasi terkait kebutuhan orang lain kepadanya. Potensi yang dimiliki subjek sesuai dengan job description supervisor penagihan dengan memberikan bantuan-bantuan teknis kepada staf jika dibutuhkan, sehingga ia mampu secara sukarela memberikan bantuannya kepada orang lain.

Potensi inisiatif subjek berada pada level 4. Potensi yang dimiliki oleh subjek menunjukkan bahwa ia mampu untuk melakukan pekerjaan diluar tugas dan tanggungjawabnya sebagai supervisor penagihan. Hal ini sesuai dengan tuntutan job description supervisor penagihan, seperti melaksanakan tugas-tugas lain sebagaimana yang ditugaskan oleh pimpinan atau atasan.

Potensi hubungan interpersonal subjek berada pada level 3. Potensi yang dimiliki oleh subjek menunjukkan bahwa ia cukup mampu membangun hubungan yang hangat dengan orang lain, sehingga tercipta hubungan yang efektif dan saling memberikan keuntungan satu sama lain. Hal ini sesuai dengan job description supervisor penagihan yang dituntut untuk memiliki 
hubungan dengan internal perusahaan yang berhubungan langsung dengan bagian akuntansi, sehubungan dengan tersedianya data untuk bagian akuntansi dan membangun hubungan dengan pihak diluar rumah sakit, seperti menghubungi dan mengingatkan perusahaan lain, karyawan dan perorangan sebelum piutang jatuh tempo dan menghubungi perusahaan, karyawan dan perorangan jika piutang sudah jatuh tempo untuk segera melakukan pembayaran.

Potensi komunikasi subjek berada pada level 3. Potensi komunikasi yang dimiliki subjek menunjukkan bahwa ia cukup mampu menyampaikan pesan yang dapat dipahami dan dimengerti oleh orang lain, hal dikarenakan ia cukup mampu untuk berbicara dengan jelas dan ringkas terhadap lawan bicaranya. Hal ini sesuai dengan job description supervisor penagihan, seperti memberikan masukan-masukan dalam bentuk saran-saran dan pemikiran kepada kepala bagian keuangan untuk perbaikan RS XX khususnya bagian piutang dan penagihan, hal ini membantu orang lain memahami apa yang disampaikannya.

Potensi kepercayaan diri subjek berada pada level 3. Potensi yang dimiliki oleh subjek menunjukkan bahwa ia cukup memiliki kepercayaan diri untuk menyelesaikan tugas dan tanggungjawabnya sebagai karyawan dengan posisi supervisor jabatan. Ia juga dituntut untuk mampu menyelesaikan pekerjaan dengan keyakinan dan menggunakan pendekatan yang efektif. Hal ini sesuai degan tuntutan jabatan supervisor penagihan yaitu, menyediakan laporan kegiatan setiap bulan kepada pimpinan, sehingga ia memiliki cukup keyakinan untuk menyelesaikan pekerjaannya dalam bentuk laporan.

Potensi kerjasama subjek berada pada level 3. Potensi yang dimiliki oleh subjek menunjukkan bahwa ia cukup memiliki dorongan untuk bergabung dan menjadi bagian dalam sebuah kelompok. Selain itu, ia cukup mampu melakukan pekerjaan bersama orang lain. Hal ini sesuai dengan job description supervisor penagihan dengan memberikan bantuan kepada staf yang membutuhkan bantuan pekerjaan.

Potensi daya tahan stres subjek berada pada level 2. Potensi daya tahan stres yang dimiliki subjek menunjukkan bahwa ia kurang mampu untuk mengelola diri dengan baik, sehingga ketika menemukan kendala pada pekerjaan dan bekerja dengan target yang menekan, ia kurang produktif dan kurang mampu untuk menyelesaikan pekerjaan tersebut. Hal ini sesuai dengan job description supervisor penagihan dengan menyelesaikan laporan secara berkala kepada kepala bagian keuangan pada waktu yang telah ditentukan, sehingga ia cenderung tertekan dan kesulitan menyelesaikan pekerjaan dengan baik.

Potensi memimpin kelompok subjek berada pada level 3. Potensi memimpin kelompok yang dimiliki subjek menunjukkan bahwa ia cukup mampu untuk memimpin orang lain. Namun demikian, ia belum memenuhi standar untuk memimpin kelompok dengan jabatan supervisor penagihan, dikarenakan tuntutan tugas yang diberikan tidak sesuai dengan potensi yang dimilikinya, sehingga ia cenderung sulit untuk memastikan kejelasan tugas setiap anggota kelompoknya.

Potensi mengambil keputusan subjek berada pada level 3. Potensi yang dimiliki subjek menunjukkan bahwa ia cukup mampu mengambil sebuah keputusan dengan melakukan evaluasi terhadap keputusan yang akan diambil. Hal ini sesuai dengan job description supervisor penagihan, seperti keputusan memberikan teguran langsung dan peringatan tertulis sesuai dengan kewenangannya kepala staf piutang dan penagihan berdasarkan wewenang yang dimilikinya, sehingga ia cukup mampu menentukan dengan bijak keputusan yang akan diambil dan diterapkan kepada anggota kelompoknya.

Potensi kemampuan merencanakan subjek berada pada level 4. Potensi yang dimiliki oleh subjek menunjukkan bahwa ia mampu membuat perencanaan dan prioritas setiap aktivitas pekerjaan yang akan dilakukannya, sehingga ia mampu menyelesaikan pekerjaannya sesuai dengan target yang telah ditentukan. Hal ini sesuai dengan job description supervisor 
penagihan yang memiliki tanggungjawab terhadap pelaksanaan protap-protap yang ada, sehingga ia mampu untuk menentukan secara matang perencanaan waktu untuk melaksanakan pekerjaan.

\section{DISKUSI}

Melalui asesmen individu sebagai upaya sistematis pengidentifikasian karakteristik dan potensi setiap klien (Gibson \& Mitchell, 2011), penelitian ini menemukan bahwa keberhasilan seseorang dalam menyelesaikan tanggung jawab terletak pada potensi yang dimiliki. Hal ini sejalan dengan pendapat (Cable \& DeRue, 2002) yang menjelaskan bahwa person-job fit adalah keadaan yang menggambarkan adanya kesesuaian antara kemampuan karyawan dengan tuntutan pekerjaan, kebutuhan individu dan apa yang dapat diberikan oleh pekerjaan itu kepada karyawan. Tuntutan pekerjaan tersebut memiliki berkaitan dengan setiap potensi dan kompetensi yang dimiliki oleh karyawan agar dapat menyelesaikan pekerjaan secara optimal.

Penelitian ini juga menemukan bahwa potensi stres yang dimiliki seseorang dapat mengganggu pekerjaan dan tanggung jawabnya, sehingga ia sulit untuk berkonsentrasi untuk fokus menyelesaikan pekerjaannya. Stres kerja yang tidak dapat dikontrol dengan baik dapat mengakibatkan menurunnya kinerja karyawan itu sendiri. Stres yang dialami individu merupakan sebuah respon diri terhadap situasi yang menantang, sehingga indiviu tersebut tidak dapat mengelola dirinya dengan baik dan mengganggu psikologis seseorang. Stres kerja (occupational stress) adalah dikarenakan adanya ketidakseimbangan antara karakteristik kepribadian karyawan dengan karakteristik aspek-aspek pekerjaannya dan dapat terjadi pada semua kondisi pekerjaan (Jum'ati \& Wuswa, 2013). Stres yang dimiiki oleh karyawan dapat berkurang melalui counselling. Konseling yang diberikan pada subjek sendiri merupakan bagian dari intervensi, sebagai seperangkat tindakan yang direncanakan dan bertujuan untuk membantu organisasi dalam meningkatkan efektivitas organisasi (Cummings \& Worley, 2015).

Konseling adalah hubungan yang berupa bantuan satu-satu yang berfokus kepada pertumbuhan dan penyesuaian pribadi, dan memenuhi kebutuhan akan penyelesaian problem dan kebutuhan pengambilan keputusan (Gibson \& Mitchell, 2011).Konseling dilakukan untuk mengurangi tekanan yang dirasakan ketika individu bekerja, sehingga dapat mengontrol tekanan yang dirasakan. Konseling diharapkan mampu mengetahui penyebab individu kurang memiliki daya tahan stres yang baik, sehingga individu mampu bekerja dengan produktif dan optimal. Melalui konseling individu juga dapat menyadari secara umum kelebihan dan kekurangan yang dimilikinya, sehingga mampu mengantisipasi kelemahan yang dimiliki dan meningkatkan kelebihannya. Hal ini sejalan dengan penelitian dari Khairani dan Fahmie (2018) menemukan bahwa counselling kerja yang dilakukan pada karyawan untuk mengetahui kelemahan dan kelebihan yang dimilikinya terutama dalam hal yang berkaitan dengan pekerjaannya, sehingga karyawan tersebut dapat memperbaiki kelemahannya dan terus meningkatkan kelebihannya.

\section{KESIMPULAN}

Berdasarkan hasil asesmen potensial review pada jabatan Supervisor Jabatan di RS XX yang telah dilakukan, didapatkan bahwa subjek memenuhi seluruh standar yang ditetapkan dan beberapa aspek melebihi standar. Aspek yang berada di atas standar adalah kemampuan melayani, inisiatif pada aspek kepribadian dan kemampuan merencanakan pada aspek kepemimpinan. Namun demikian, ada satu aspek yang berada di bawah standar yang ditetapkan yaitu pada aspek daya tahan stres yang termasuk ke dalam aspek kepribadian. Hal 
ini tentu akan berpengaruh pada kinerjanya jika tidak dikelola dengan baik, sehingga rekomendasi yang dapat diberikan kepada subjek adalah masih dapat dikembangkan untuk posisinya sebagai supervisor penagihan dengan pengembangan counselling yang bertujuan untuk mengoptimalkan potensinya sebagai seorang karyawan.

\section{UCAPAN TERIMAKASIH}

Terimakasih kepada Rumah Sakit XX yang telah memberikan kesempatan dan izin kepada penulis untuk mengambil data. Terimakasih juga penulis berikan kepada Universitas Ahmad Dahlan yang telah memfasilitasi penulis dalam perizinan. Selain itu, penulis juga mengucapkan terimakasih kepada kedua orangtua dan kedua adik tercinta yang telah memberikan dukungan baik moril maupun materil untuk menyelesaikan penelitian ini. Semoga Allah SWT membalas segala kebaikan yang telah diberikan dengan pahala yang berlipat ganda aamiin.

\section{DAFTAR PUSTAKA}

Cable, D.M, \& Judge, T.A. (1997). Interviewers' Perceptions of Person-Organization fFit and Organizational Selection Decisions. Journal of Applied Psychology, 82(4):546-561.

Cummings, T. G., \& Worley, C. G. (2015). Organization Development \& Chang. South Western: Thompson.

Dharmaraj, D. A., \& Mohammed Sulaiman, I. (2015). Employee's Perception of Potential Appraisal (A Study among Managerial Cadre Employees in Public Sectors in Kerala). Bonfring International Journal of Industrial Engineering and Management Science, 5(4), 155-161.

Gibson, R. L., \& Mitchell, M. H. (2011). Bimbingan dan Konseling. Yogyakarta: Pustaka Pelajar.

Hasibuan, M. S. (2013). Manajemen Sumber Daya Manusia. Jakarta: PT. Aksara.

Jum'ati, N., \& Wuswa, H. (2013). Stres Kerja (Occupational Stress) yang Mempengaruhi Kinerja Individu pada Dinas Kesehatan Bidang Pencegahan Pemberantasan Penyakit dan Penyehatan Lingkungan (P2P-P1) di Kabupaten Bangkalan. Jurnal NeO-Bis, 4(7).

Khairani, D, A., \& Fahmi, A. (2018). Potential Review Karyawan Hotel X Sebagai Dasar Pengembangan Sumber Daya Manusia. The National Conferences Management and Business (NCMAB), 2621-1572.

Lincoln, Y. V., \& Guba, E. G. (1985). Naturalistic Inquiry. California: Sage.

Moloeng, L. J. (2012). Metodologi Penelitian Kualitatif. Bandung: PT Remaja Rosdakarya.

Munandar, M. (2010). Budgeting Perencanaan Kerja Pengkoordinasian Kerja Pengawasan Kerja. Yogyakarta: BPFE.

Nurhayati, R., \& Santoso, A. (2018). Hubungan antara Ekspresi Gambar Orang dan FaktorFaktor Kepribadian 16PF. Psikologika: Jurnal Pemikiran Dan Penelitian Psikologi, 23(2), 165-182.

Tjiptono, F. (2006). Manajemen Jasa Edisi IV. Yogyakarta: Andi.

Sahyadi, D. Y., \& Harsanti, I. (2018). Rancang Bangun Tes Kraepelin Berbasis Website. Jurnal Ilmiah Informatika Komputer, 23, 223-235.

Savira, A. W., \& Hidayat, R. (2017). Validitas Prediktif PAPI-Kostick dan BAUM terhadap Pengendalian Emosi Karyawan. Jurnal Psikologi, 44, 223-235. 
Prabowo, A., Nisa', A. C., \& Jadmiko, G. T. (2016). Profil Kepribadian Tes Wartegg (Studi Deskriptif pada Seleksi Karyawan). Semina Asean, 23-27.

Roivainen, E. (2009). A brief history of the Wartegg Drawing test. Gestalt Theory, 31(1), 5571.

Wikansari, R. (2014). Efektivitas Behevioral Event Interview dalam Proses Asesmen Tenaga Kerja. Majalah Manajemen Industri dan Perdagangan, 16(2), 935-941. 